\title{
Blasphemy in an Age of Corroding Secularity
}

\section{Jasper Doomen ${ }^{1}$}

Published online: 13 June 2020

(c) The Author(s) 2020

\begin{abstract}
'Sacred' may be defined in various ways, depending on one's worldview. In a pluralistic society, a single perspective from which to decide what is sacred seems absent. Yet certain elements are taken to be sacred such that they transcend individual worldviews. Their inviolability entails blasphemy laws, where 'blasphemy' extends beyond what is traditionally considered religious, since 'religion' itself is not clearly demarcated either. The interests of the sacred may be protected by blasphemy laws, but the downside of such laws is that the freedom of expression is compromised. A balanced view is necessary to accommodate these conflicting interests.
\end{abstract}

Keywords Blasphemy $\cdot$ Constitutional law $\cdot$ Freedom of expression $\cdot$ Sacred

\section{Introduction}

It is not generally agreed upon that acts of blasphemy are punishable or even objectionable. A position such as Aquinas's, who maintains that blasphemy is a greater sin than murder (1895, 2a2ae, q. 13, art. 4, p. 110), comes across, in liberal democratic states, as outlandish. Still, if 'blasphemy' is not understood in the narrow sense in which Aquinas (who considers it to be a direct sin against God) defines it, blasphemy may, although it may not generally be considered a great $\sin$, be argued to be forbidden. I will indeed maintain that a broad conception of 'blasphemy' is manifested in laws that forbid actions that are not associated with a defamation of the Christian God or another deity.

To that end, I will first, in Section "The Sacred and the Secular", inquire into the idea of the 'sacred'. If there is no compelling reason to accept a special conception of 'sacred' in accordance with a certain creed and reject conceptions stemming from alternative creeds, the idea of the 'sacred' is not necessarily discarded once a perspective is taken that is supposed to represent all creeds, for the alternative is that a general idea of what is 'sacred' is accepted, such that it may be accepted in various

Jasper Doomen

jdoomen@gmail.com

1 Open Universiteit, Valkenburgerweg 177, 6419 AT Heerlen, The Netherlands 
creeds. This is what has indeed happened; the national flag and (in countries with a monarchy) majesty can be mentioned here as examples.

If such a general acceptance brings with it that expressions that defame what is 'sacred' should not be allowed, it engenders a broad conception of 'blasphemy'. This is what is inquired into in Section "The Range of 'Blasphemy"'. Should actions such as flag desecration and lèse-majesté, which may, under that conception, be said to constitute blasphemy, be punishable? The controversial issue of Holocaust denial in particular will be considered. The question whether Holocaust denial should be allowed cannot, I will argue in Section "Consistency One Way or the Other", be answered in general: the context in which it is expressed must be taken into consideration. This section is focused on the freedom that should exist for someone who does not agree with a certain conception of 'sacred' to express something that may be taken to be defamatory. It explores in particular the position of a minority in a situation where 'sacred' elements are commonly accepted and defamatory expressions that refer to them are forbidden.

The object of this paper is to determine, taking the interests seriously of those who consider certain things to be sacred and of those who claim the freedom to express themselves in such a way that their expressions may be regarded by the first group of people as insulting, in such a way that a balanced and consistent end result will be reached.

\section{The Sacred and the Secular}

In order to determine whether blasphemous expressions are unacceptable and should, as such, be punishable, it is necessary to first inquire into the subject of such expressions, namely, that which is sacred. Durkheim has explored the issue in detail; his position is a proper starting point. His definition is:

By sacred things one must not understand simply those personal beings which one calls gods or spirits; a rock, a tree, a spring, a pebble, a piece of wood, a house-in a word, anything can be sacred. A rite can have this character; a rite that does not have it to some degree does not even exist. (Durkheim 1960, p. $51)^{2}$

Durkheim points to the special character of the totem, which is deemed 'the very type of sacred things, ${ }^{3}$

\footnotetext{
${ }^{1}$ It is even broader than the following conception: 'The type of expression banned by blasphemy laws around the globe ranges from the destruction of holy books to statements that call into question religious beliefs to depictions deemed disrespectful of God or holy figures.' Aswad et al. (2014, p. 127).

2 'par choses sacrées, il ne faut pas entendre simplement ces êtres personnels que l'on appelle des dieux ou des esprits; un rocher, un arbre, une source, un caillou, une pièce de bois, une maison en un mot une chose quelconque peut être sacrée. Un rite peut avoir ce caractère; il n'existe même pas de rite qui ne l'ait à quelque degré.' Durkheim (1960, Book 1, Ch. 1, section 3, p. 51).

3 'le totem [...] est le type même des choses sacrées.' Durkheim (1960, Book 2, Ch. 1, section 3, p. 167).
} 
A good illustration is a flag, and in particular the national flag. ${ }^{4}$ It has no value of its own (save for the cloth, which is not a relevant factor here) and its significance is indirect in the sense that it is supposed to represent a state: 'Many Americans consider the flag sacred because of its conventional association with the life of the nation; the respect they believe they owe their country is transferred to the flag' (Dworkin 1994, p. 74). The individual, acknowledging this significance, clings to it, which is expressed most gravely in the case of those defending their country: 'The soldier who falls while defending his flag surely does not believe that he has sacrificed himself for a piece of cloth.' 5

If the national flag indeed represents the state, the question presents itself as to what 'state' means. 'State' is an abstract term; substituting 'country' for it is not very helpful. 'State' may be (somewhat) concretized by referring to the values it is supposed to represent, but an important problem for this approach to be convincing is that in states with pluralistic societies citizens may disagree on even basic values. This problem readily comes to the fore. Yelle observes:

For Americans, the U.S. flag is equivalent to what used to be called a totem, a symbol of the group. Émile Durkheim developed an anthropological account of the totem in identifying society itself or the group's sense of identity as the source of the sacred. (Yelle 2014, p. 154)

Still, if a sense of common identity is not as evident as it may once have been, the meaning of what the totem is supposed to represent may be questioned. Moon rightly observes that groups of people, on the basis of their divergent creeds, may disagree on what should be considered 'sacred', just as individuals disagree amongst themselves (Moon 2018, p. 104).

It is difficult, if possible at all, then, to establish what is sacred, at least insofar as 'sacred' in an absolute sense, i.e., 'sacred' as such (so presumably something that is sacred even if no one acknowledges this), is concerned. ${ }^{6}$ This has important ramifications for the storage rooms of what is sacred, namely, religions. Durkheim defines 'religion' as follows: 'A religion is a unified system of beliefs and practices relative to sacred things, i.e., things that are separated; these beliefs and practices unite in a single moral community, called a Church, all who subscribe to them.' ${ }^{, 7}$ According to this conception, then, 'church' has a broader reference than 'church' as it is used (specifically) in Christianity.

\footnotetext{
${ }^{4}$ Brent Plate (2006, p. 163): 'Nations, like religions, do not develop, reform, and sustain themselves by abstract doctrine alone. Rather, they construct myths, symbols, and rituals to buttress the system. With regard to nationalism, one of the strongest symbols is that of the flag.'

5 'Le soldat qui tombe en défendant son drapeau ne croit certes pas s'être sacrifié à un morceau d'étoffe.' Durkheim (1960, Book 2, Ch. 7, section 4, p. 326; cf. Book 3, Ch. 1, section 4, p. 462).

6 An attempt to define it has the risk of either excluding something vital or being so broad as to include so much that it becomes unclear. An example of the latter case is the following: 'The sacred refers to beings (human and otherwise), places, objects, and times which are elevated, and are charged by divine and/or human forces with power beyond that of the commonplace.' Brent Plate (2006, p. 37).

7 'Une religion est un système solidaire de croyances et de pratiques relatives à des choses sacrées, c'està-dire séparées, interdites, croyances et pratiques qui unissent en une même communauté morale, appelée Église, tous ceux qui y adhèrent.' Durkheim (1960, Book 1, Ch. 1, section 4, p. 65).
} 
Those who would argue that such a perspective leads to a diminishment of the worldviews that are traditionally acknowledged as religious (such as Christianity), or perhaps to religion inflation, would bear the burden of indicating what, exactly, makes traditional religions special in comparison with other worldviews. They may point out that adherents of those religions actually worship the divine. Even if it is granted, arguendo, that a religion such as Hinduism is not a traditional religion and that the Abrahamic religions have the same conception of 'the divine', the burden has not been removed for such adherents to show, first, that a religious entity exists at all; second, that some special relationship with such an entity exists for them when they practice their religion; and, third, what the relevance is of the first two truths.

If they are unable to do so, they may retort that such a burden of proof would be too onerous and that it suffices to appeal to the fact that something important for them is at stake. If this is what they argue, those whose worldview is not associated with the divine may claim that they should be taken just as seriously: 'Secular citizens may be motivated by Marxism, libertarianism or certain economic views-doctrines that are often just as deeply steeped in ideological commitments and idiosyncratic assumptions as their religious counterparts' (Blum 2018, p. 7).

One may, of course, differ with respect to what constitutes a religion and, consequently, how 'religion' should be defined. One may, for example, maintain: 'The term sacred is stretched beyond "religion", leaving traditional truths and virtues behind it, and used interchangeably with terms like "spiritual" (Burns Coleman and White 2006, p. 65). The idea that it is possible for something to be considered sacred outside the purview of a religion does not appear to correspond with Durkheim's definitions, but that is no vital issue as one is of course free to depart from Durkheim's view. Still, it may be questioned whether one can still speak of 'secularly' in such cases if it is observed that

The term sacred is also applied secularly, in relation to such things as the State, memorials and ANZAC Day, and even property. The stretching of 'the sacred' to this application of the term sacred was made possible through the analysis of the concept within the social sciences, in particular, by Emile Durkheim. (Burns Coleman and White 2006, p. 66)

This brings with it a discussion of its own, this time regarding the definition of 'secular'.

With respect to 'religion', the following can be observed here. If what I have sketched above is correct, it is not crucial that a clear demarcation line be drawn (or that it at least be agreed upon) between 'religion' and 'non-religion': if the element of the divine cannot be decisive and if it is acknowledged that those who adhere to non-religious worldviews do so on account of the fact that something importantfor them-is at stake, there is no reason to accord special significance to that which religious people consider sacred outside of the religious context in which they do so themselves, amongst each other. 
A 'secular' domain may be defined as one in which religious elements have no special significance. A liberal secular state does not seek to expel religions or forbid worshipping a religion, but simply does not offer special treatment to religions or believers. Importantly, it appears difficult to distinguish between 'secular' and 'religious' in situations where something is deemed significant by one or more nonbelievers (meaning here those who do not identify as (traditionally) religious persons) to such a degree that it may be considered something sacred by them.

The national flag is, again, a good example. An individual need not acknowledge the existence of a deity (in whatever sense) in order to regard the flag in a special way, namely as representing the state or the values for which it supposedly stands. Those values, which may, of course, also be defended without referring to a symbol such as a flag, may be deemed 'moral values'. Jones signalizes a 'transposing' of religious elements to a secular domain:

Any religious activity can be seen as historical or cultural phenomena or as creating an atmosphere of dignity. Religion in general also has effects in the secular realm, such as inculcating moral values. If an objective of creating such effects is accepted as a sufficient secular purpose, virtually any religious activity could be advanced by the government. (Jones 1989, p. 394)

It may be argued, though, that even irrespective of such an operation religious elements ('religious' taken in the broad sense indicated above) are present in 'secular' states; if a state is indeed permeated by such elements it is not truly secular. Even if one does not appeal to a divine source in order to uphold 'moral values', the very meaning of 'moral values' may be questioned. It is not possible to defend the existence of such values scientifically ${ }^{8}$ or logically and they are arguably religious. The same consideration applies to the notion of 'dignity' (or, specifically, 'human dignity'). It appears difficult to make it clear what, exactly, 'dignity' means (Doomen 2016, pp. 58-66) and this notion, too, may be said to be religious. As Brent Plate observes: 'Modern liberal societies redefine rather than banish the sacred, in spite of their best wishes' (2006, p. 136).

Certain values (sometimes represented, for example, in the guise of a flag) may be considered sacred even if they do not stem from a worldview that is religious in the traditional sense and may, as such, be considered to find a meaning (for some people) in a religious sense, if 'religion' is, again, understood in the broad sense used here. A secular state in which such values are generally acknowledged is, consequently, strictly speaking, secular in name only. Blum's perspective is slightly different:

\footnotetext{
${ }^{8}$ In fact, on the basis of findings in biology one may identify the source of (some of) such values as a survival mechanism of the group (and thus, in some cases indirectly, the individual and/or its offspring). A case in point is the act of sharing blood between vampire bats: a bat that has collected more than enough blood shares it with a fellow bat that has not been successful. One need not accept such a reductionist account (and may argue, in particular, that the considerations in the case of human beings cannot be reduced to such behaviour), but dismissing it does not remove the burden of proving that the values in question have an alternative or superposed meaning.
} 
Like its supposed counterpart, secularism can [...] propagate values and ideals that inform behavior and beliefs about public policy (laicité), and be interpreted to produce foundational principles that are non-negotiable for those who endorse them (freedom of speech). Secularism is therefore just as capable of producing the kinds of hurdles to public debate that religion is typically accused of producing. Thus, theoretically, the supposed boundary between 'the religious' and 'the secular' is far less clear than many acknowledge. (Blum 2018, p. 6)

Once elements are generally accepted as sacred in a state, it ceases to be secular and becomes religious. ${ }^{9}$ That some elements are not explicitly recognized to be sacred means that questioning their meaning may not be as easy as questioning, e.g., the truth of the Trinity in Christianity, as certain values may be considered to be so obvious that even doubting whether they are self-evident may be considered offensive. I just said 'generally accepted'; citizens may still, in a (sufficiently) liberal state, express conflicting views. The question as to what extent such views should also be accepted - and not rather dismissed as (unnecessarily) offensive-is the focal point of the remainder of this paper.

\section{The Range of 'Blasphemy'}

Blasphemy laws are made if sacred items are deemed worthy of protection against offence:

Blasphemy [...] entails the irreverent or outrageous treatment not of a religion, but of those matters that a religion holds sacred. Necessarily, therefore, any 'harm' which blasphemy causes to religious devotees must be in the form of hurt to religious sensitivities and consequent anger and upset. ${ }^{10}$

Holzapfel rightly observes that the definition of blasphemy "varies widely by interpretation, culture, context, and perception' (Holzapfel 2014, p. 634). If the broad interpretation of 'sacred' and 'religion' presented in Section "The Sacred and the Secular" is accepted, an equally broad meaning should be used in the case of blasphemy: 'blasphemy has [...] moved from the realm of traditional religion into modern, secular society and the targets of blasphemy have been redirected' (Brent Plate 2006, p. 133). This may be referred to as cultural blasphemy (Patrick 2011 p. 206).

\footnotetext{
9 Yelle makes a category mistake, then, as do Burns Coleman and White (2006, p. 66), when he maintains that 'Many Americans regard the flag as inviolable, the secular form of a sacred object, considerably more than an arbitrary expression of national identity' (Yelle 2014, p. 155). The flag is not a secular form of a sacred object; rather, its presence as a sacred object detracts from the secular character of the state, albeit possibly only slightly.

${ }^{10}$ Cox (2016, p. 201). Incidentally, Cox-implicitly-appears to adhere to a broad understanding of 'harm' here. As will become apparent in Section "Consistency One Way or the Other", my conception of 'harm' is not limited to physical harm either.
} 
Support for blasphemy laws protecting what was traditionally considered 'sacred' is perhaps not as common as it may have been at the time of their introduction. On the other hand, offending supposedly 'secularly sacred' things-which is, in accordance with what has already been remarked, an oxymoron-is in some cases forbidden on the basis of what seem to be considered non-debatable considerations. The position of 'human dignity' is a case in point. The notion features prominently in various treaties. The Preamble to the International Covenant on Civil and Political Rights specifically mentions 'the inherent dignity' of human beings, which is apparently considered a veritable moral axiom.

Whether one or more new conceptions of 'sacred' have, in some cases, replaced the traditional conceptions and, if so, how this may be (sociologically) explained is a question that lies beyond the scope of this paper. What is important to observe here is that 'sacral' notions, both traditional and secular ones, share the common problem that those who adhere to the worldviews from which they stem have to appeal to something not evidently true. If something evidently true were at issue, (virtually) all citizens would accept it; should a (small) number of citizens not accept it, it would be easy to demonstrate that they simply have not understood what was said, in contradistinction to a situation in which multi-interpretable or even potentially meaningless notions are used.

To return to the notion of '(human) dignity', even those who accept this notion as the basis for (refraining from) acting are unable to demonstrate what this means (cf. Doomen 2016, pp. 58-66), which is one of the reasons to consider an appeal to it as religious. The following quote is illustrative:

Respect is a key term for the understanding of human rights in general and in particular for freedom of religion or belief. In the human rights framework, respect always relates to human beings, as evidenced in the opening sentence of the preamble of the Universal Declaration of Human Rights, which proclaims the 'recognition of the inherent dignity and of the equal and inalienable rights of all members of the human family'. In the face of widespread misunderstandings, it cannot be emphasized enough that freedom of religion or belief does not provide respect to religions as such; instead it empowers human beings in the broad field of religion and belief. The idea of protecting the honour of religions themselves would clearly be at variance with the human rights approach. (Bielefeldt 2013, section 33)

Bielefeldt is right to observe that freedom of religion concerns the (negative) freedom individuals have to manifest religion, but it is not clear what he means when he argues that respect relates to human beings. Human beings are presumably not worthy of respect on account of a specific characteristic ${ }^{11}$ in the sense of respect for certain individuals who have accomplished something on the basis of characteristics they have and others lack; crucially, those others do not merit the same respect

\footnotetext{
11 It may be concluded from this passage (and more clearly on the basis of section 31 in the same text) that the basis for respect is 'dignity', but this only obscures matters since 'dignity' is itself the explanandum.
} 
in this sense since it would otherwise have no meaning. After all, in the case of 'dignity', something is at stake with which every human being is (presumably) 'inherently' endowed.

There are a number of problems with the idea of 'dignity'. There is no need to provide a detailed account here, and I merely observe that it is unclear what, if anything, it means and on what basis human beings are supposedly endowed with it. If individuals were free to acknowledge or reject the idea that all human beings are endowed with 'dignity' (and that it has a meaning in the first place), the situation would be the same as in the case of a creed one is free to adopt or refuse; in the case of treaties that include the notion, however, a compelling conceptual framework serves as the basis for the rights that are guaranteed. The given that these rights can be guaranteed without such an appeal relativizes this problem (while raising the question, on the other hand, as to what the added value of presenting the notion would be), but only insofar as the rights themselves are concerned. ${ }^{12}$ This relativization does not apply, however, in the case of blasphemy legislation that forbids assaulting the 'dignity' of one or more individuals, for such legislation restricts the freedom of expression and of religion. ${ }^{13}$

The pertinent German legislation, namely, Section 130, subsection 4, of the penal code (Strafgesetzbuch), provides a good illustration. ${ }^{14}$ It is forbidden to publicly or in an assembly disturb the public peace in such a manner that the dignity (Würde) of the victims is violated by approving of, glorifying, or justifying National Socialist rule of arbitrary force. (In subsections 1 and 2 of this section, human dignity (die Menschenwürde) is safeguarded generally, so without a necessary association with the Holocaust, by forbidding, among other things, insulting people because of their race.)

On the basis of subsection 3 , it is forbidden to approve of, deny or trivialize an act of genocide committed under the rule of National Socialism in a manner capable of disturbing the public peace. ${ }^{15}$ In this case, violating 'dignity' is not part of the offence, but something that is considered sacred may still be said to be safeguarded here, too; 'sacred' is to be interpreted in such a way as to include things or events that are-generally-considered lamentable (and, in the case of events, commemorated as such). ${ }^{16}$ Still, it seems peculiar to consider something that is absent sacred,

\footnotetext{
12 With the exception, of course, of those articles which themselves include the term 'dignity', such as article 10 of the International Covenant on Civil and Political Rights.

13 The freedom of religion at issue here is the freedom of adherents to a religion to express, on the basis of their own religious beliefs, something such that the 'dignity' of (certain) individuals is assaulted, even if one accepts my position that 'dignity' is itself a religious notion. (Presumably, someone who would indeed act thus, on the basis of his or her own religious beliefs, would do so on the basis of another religious conviction.).

14 It is understandable, of course, given Germany's history, what prompted it.

15 Section 3h of the Austrian Prohibition Act 1947 ('Verbotsgesetz 1947') similarly forbids denying, grossly trivializing, condoning or trying to justify in a printed work, in broadcasting or in any other media or otherwise publicly the National Socialist genocide or other National Socialist crimes against humanity.

16 Cf. Tatz's evaluation: 'For many, [the Holocaust] has become a sacred event, metahistorical, beyond words, analysis and deconstruction.’ Tatz (2006, p. 80).
} 
so that it may be more apt to say, forgoing this negative interpretation, that the event that is considered sacred is the death of those who were the victims of the Holocaust, including humanity as such, personified by them. This raises the question as to what 'humanity' is and why it should be considered something special and as such be protected, but an analysis of that issue lies beyond the scope of this paper.

This section has focused on reasons to realize blasphemy laws, 'blasphemy' having been taken broadly. The final issue to be discussed is what the legitimacy of such laws may be.

\section{Consistency One Way or the Other}

A corollary of Section "The Range of "Blasphemy"” is that the demarcation line between defamation in general and blasphemy appears to be difficult to draw, given what was argued in Section "The Sacred and the Secular". If 'blasphemy' is taken broadly, the object of the insult being something sacred in the sense presented in this paper, laws that are created to protect elements and values such as those mentioned in Sections The "Sacred and the Secular" and "The Range of "Blasphemy" may for that reason be called blasphemy laws.

There are basically two ways to assess blasphemy laws. The first option is to hold that not just that which has traditionally been considered religious should merit special protection (such as God), but everything that is qualified as religious. Blasphemy laws should, in this view, apply as broadly as possible, and have as their object everything considered sacred. 'Religion' is thus defined individually: the believer claims that something religious is at issue which should, as such, be protected. By adopting this option, the given that religious beliefs may be 'deeply held and faith-based, a matter of identity rather than judgment' (Moon 2018, p. 107) is taken seriously. Someone who defends this position may still hold that 'everything considered sacred' should be qualified, where 'considered' should be interpreted as 'commonly considered' rather than as 'individually considered', since 'sacred' would otherwise arguably have no meaning, but that raises the question (and attacks the premise of his account) what exactly makes something sacred and, as a consequence, what qualifies as religious.

The second option is to hold that 'sacred' and 'religion' are categories that should not be the object of legislation, or at least that there is no reason to hold that they should merit the special protection that is afforded by blasphemy laws.

The demarcation line between 'religion' and 'non-religion' is difficult to uphold, but that given does not in itself provide an answer to the question as to which of the two options should be accepted. It does not entail that additional protection for what was not traditionally considered religious but is presently qualified as such is justified, nor that it should receive special protection on account of its religious character; in a pluralistic society, granting traditional religions special protection is hard to defend, even irrespective of the given that 'religion' is difficult to define in the first place.

That it is difficult to define 'religion' is no trivial or merely academic matter if those who are considered to hold religious views and act upon them are afforded 
special protection. Who should decide whether something qualifies as a religion and, consequently, as sacred? If those who consider themselves religious are to decide the issue, so that an individual standard is used, the culmination of the religion inflation mentioned in Section "The Sacred and the Secular" is realized. If, by contrast, lawgivers are to have the final say, the question presents itself as to what in particular would qualify them to act as theologians, and, supposing they were equipped for this task, it is an understatement to say that theologians do not always agree on matters of religion.

What is characteristic of 'religion' is difficult to say, but one may inquire why religion inflation poses a problem at all. If a mere theological issue were at stake, without consequences for those who do not identify as religious ${ }^{17}$ and steer clear of such issues, no difficulties would arise (except for those which might emerge in a situation where adherents of conflicting religious views do not tolerate each other). If religious elements are afforded special protection, however, at the expense of those who want to have the freedom to criticize such worldviews, that freedom is compromised. (To what extent such freedom should be allowed to exist will briefly be discussed below.) As long as it is not clear how 'religion' is to be differentiated from 'non-religion', there is no reason to treat 'religion', whatever it may mean, in a special way.

It seems best to suspend judgment on the matter and concur with Blum when he says:

Rather than searching for criteria that serve to distinguish either religious from secular discourse or acceptable from unacceptable kinds of public speech, I suggest abandoning that project and simply allowing conflicting viewpoints into the public square, without preconditions or categorizations, in order for them to compete for public support [...]. Such a situation ensures the protection of religious speech just because it is free speech. It also ensures the ability of individuals - both religious and other-to criticize the positions of their fellow citizens. (Blum 2018, p. 14).

This entails accepting the second of both options.

It may be objected that not making Holocaust denial punishable as a consequence of the given that its 'sacred' nature (in the particular sense of 'sacred' with respect to the Holocaust presented at the end of Section "The Range of 'Blasphemy") is not acknowledged results in a lack of respect to those who have died and their descendants:

protecting the dead from disrespect-a key goal of Holocaust denial laws-is a common feature across human societies. The same goes for showing respect to survivors. Therefore, even a modern secular society can justify a ban on Holocaust denial without wading into theology. (Kahn 2011, p. 105)

\footnotetext{
17 It may, incidentally, be argued that every position is religious, especially if an individual standard is accepted, but the issue here is not whether non-religious position exist (or are even possible), but rather what the consequences are of qualifying something as religious.
} 
It is doubtful, however, in light of what was argued above, whether wading into theology is indeed avoidable. In any event, should one think that the interests of these persons should be protected, insult laws should suffice for this goal, presuming that an insult takes place in this case and should as such be punishable. Religious speech should, then, be treated in the same way as other kinds of speech.

It must be stressed that accepting an individual standard for 'religion' has important consequences, unless no special protection is afforded to religious elements in the form of blasphemy laws. If such special protection is afforded, this comes at the expense of those who want to have the freedom to criticize such elements or the worldviews that attribute a special (religious) significance to such elements.

Examples of laws against Holocaust denial were presented in Section "The Range of "Blasphemy"'. Crucially, the interests of those who might be offended and of those who (for whatever reason) would deny (or belittle) the events are to be balanced. Should the issue be purely historical (those who deny the events doing so because they truly believe that they have not occurred), there should be room to express one's views either way, what has happened hopefully becoming apparent on the basis of research; if the evidence is indisputable, someone who expresses a view that conflicts with it does not have to be taken seriously. History is to be approached scientifically ${ }^{18}$ and with as little government interference as possible. Historians in liberal democratic states record history, while leaders of totalitarian states create it.

For such cases where that which is expressed extends beyond the scholarly arena and is offensive, however, a criterion is needed to decide whether the offensive expression should be allowed. Substituting an individual standard with respect to unacceptable offence (meaning that individuals should decide for themselves when they are offended in such a way that the freedom of the offender should be abridged) for an individual standard of religion will in practice yield nothing; only an aesthetic change is realized by the omission of the term 'religion'.

A criterion that steers clear of these concerns must be used to decide what qualifies as an offence. A detailed inquiry into this matter extends beyond the scope of this paper, so I refer to my presentation of such a criterion (dubbed the ignore principle) elsewhere (Doomen 2014, Chs. 10, pp. 109-126; and 11, pp. 127-135), and suffice by remarking the following. The interests of religious devotees who claim to be harmed should be taken seriously by having those who claim to be harmed defining 'harm', so individually (just as 'religion'), which means that 'harm' is not limited to physical harm. An important consideration here is that those who do not share those adherents' worldviews may not be able to put themselves in their place and understand why certain expressions are hurtful.

No-one should have to suffer something which cannot reasonably be ignored. As the 'reasonably' aspect suggests, in this case no individual standard is used. Rather, what someone may be asked to tolerate is what he would disallow if he had the power to do so but must accept now that he is (just) a citizen. The reason why he should tolerate it is that there should be room for the freedom of others to express themselves,

\footnotetext{
18 Whether one considers the discipline of history a science depends upon one's definition of 'science', but this issue does not need to be explored here.
} 
which is the same room he may consider desirable if he wants to express himself concerning an issue others may consider offensive, which they, in turn, are to reasonably ignore. Whether something may be reasonably ignored depends on the circumstances.

I readily grant that using the term 'reasonably' introduces vagueness (Doomen 2014, Ch. 10, section 10.6, p. 116) and that saying that something 'depends on the circumstances' does not provide much clarity, but this is inevitable, given the fact that the context in which something is expressed must be taken into consideration when the decision whether it is unacceptable to do so must be made. ${ }^{19}$ This does not exempt me from the burden to make it clear what I mean, though. I refer to the Goeree case ${ }^{20}$ to illustrate what I mean. A married couple were not allowed to express their religious view that the Holocaust was the result of the Jewish people not having recognized Christ as their saviour. The Dutch Supreme Court confirmed the lower court's ruling that they had expressed themselves needlessly grievously, hurtfully and disparagingly towards Jewish people. Incidentally, no appeal to something 'sacred' was made by the courts; this element is apparently not necessary to protect the people in question.

It may be argued that a view such as this should be allowed to be expressed (presuming that it is not accompanied by a call for violent actions); I would, in a (liberal democratic) state in which Jewish people, or another minority, are not marginalized and are able to reasonably ignore what is stated about them, leave room for such a viewpoint to be expressed. If the same statements are made, by contrast, in circumstances in which a minority lives in fear of aggression against them, they cannot reasonably be expected to be accepted by that minority. (A lawsuit may under such circumstances not even be an option for the people in question (anymore), but that is a separate issue.)

Even if it is granted that individuals should, depending on what is expressed, accept that what they consider sacred is referred to in a defamatory way by others, on the basis of the ignore principle or a similar standard, it may be argued that society as a whole is affected by blasphemy and that blasphemy laws are in that light in order. One may, accordingly, caution against the arguably reductionist stance taken in this paper and against, as a consequence of such a stance, too easy a dismissal of a presumably sacred symbol as a mere symbol in cases where something is at stake whose significance is not limited to what individuals who adhere to a specific creed acknowledge as sacred within the framework of that creed.

To revisit the example of the national flag as such a symbol, which supposedly represents the essence of a country, those who desecrate it may be said to indirectly spurn the values it is supposed to represent. ${ }^{21}$ The crucial question is which values may be at issue here and what their purpose may be. In Section "The Sacred and the

\footnotetext{
19 Moon states, in a similar vein: 'The judgment that expression is valuable and worthy of protection, or is instead harmful and appropriately subject to restriction (that it is not simply uncivil or confrontational but is instead harassing or intimidating or manipulating), is a relative one that will depend on a number of factors, including the form of the expression and the context in which it occurs.' Moon (2018, p. 32).

20 Dutch Supreme Court June 5, 1987; case no. 13274 (civil case)/November 18, 1988; case no. 83732 (criminal case).

21 The flag can also be burned by someone who does not oppose these values but merely wants to protest against certain current policies. This situation is only relevant, as far as this paper is concerned, insofar as the fact that the flag as a 'sacred' object is burned is at stake.
} 
Secular" such values were presented in the context of the analysis of the meaning of 'sacred'.

At this point, some problems with blasphemy laws having been presented, the next-and final-step is to establish why such values should be protected and in whose interest, if not the individual citizen, whose position has already been discussed. According to Cox,

the principle behind a blasphemy law is one that, in fact, finds significant acceptance within at least one strand of orthodox Western legal thought—one manifest, for example, in laws prohibiting Holocaust denial. This is the principle that certain speech may be legally restricted if it is profoundly immoral, and consequently, profoundly offensive from the standpoint of the community at large, as distinct from, though obviously including, the standpoint of an individual or individuals within that community. (Cox 2014, p. 745)

It is clear that the relevant issue is addressed here, since what is considered significant from the point of view of the community as such, (so apart from what individuals may think, each on his own), is argued to be at stake.

One wonders, though, what 'the standpoint of the community at large' might be. If the community as some sort of abstract entity is supposed to be the subject matter, it is difficult to imagine what exactly this means, let alone how such an entity could have a standpoint. If, alternatively, this standpoint is supposed to represent what all individuals think, it must (if a liberal democracy is concerned) be considered a fiction (I cannot, in any event, think of something on which all citizens, given the strongly diverse views to which citizens adhere amongst themselves, agree) and, apart from that, the issue would be moot: if every citizen considers certain speech so immoral that it should be legally restricted, no citizen would blaspheme. What is possible, by contrast, is to concretize 'the standpoint of the community at large' by identifying what it in fact is, namely, the standpoint of the majority of the people of which the community is composed. This means that a minority's right to express a view that is considered blasphemous by the majority is restricted, with the effect that the freedom for the minority in question is (too strongly) curtailed.

No less problematical is Cox's position when he maintains that Holocaust denial laws exist 'for the sake of the community rather than disparate individuals living within the community' (Cox 2014, p. 752). He does acknowledge that 'the community as a whole' being outraged is not to be taken to mean that every individual within the community shares this outrage (Cox 2014, p. 752), and rightly so, but this means that 'the community as a whole' is in fact a misleading notion or at least a mere fiction; it is more apt, again, to simply speak of 'the majority of the community'. 22

Dworkin defines 'sacred' by saying that 'Something is sacred or inviolable when its deliberate destruction would dishonor what ought to be honored' (Dworkin 1994, p. 74). This is not very enlightening, though; it raises the question of who

\footnotetext{
22 MacIntyre remarks that 'the use of a conceptual fiction in a good cause does not make it any less of a fiction.' MacIntyre (2007, p. 64). Furthermore, one may even wonder whether the cause is good.
} 
proclaims this standard (and thus prescribes what ought to be done). Dworkin apparently appeals to a majority when he speaks of what 'we' think when the 'sacred' is concerned (Dworkin 1994, pp. 71-81), sometimes apparently acknowledging this by saying 'most of us' (Dworkin 1994, pp. 71 and 72) and 'many people'. ${ }^{23}$ Moreover, even if it is supposed that everyone shares an idea or intuition about the 'sacred' in common, that given does not in itself prove that something is indeed sacred as such, or 'intrinsically valuable' (Dworkin 1994, pp. 73, 74) (if that is possible at all); it may alternatively be said to have a meaning solely within the context of a creed. The general acceptance of a creed does not change this.

An alternative is to argue that a specific standard of morality should be observed:

God is the source of all true morality and therefore informs every moral and ideological insight of the genuine religious devotee, Muslim or otherwise. Therefore, for that person, the undermining of God by gross irreverence involves the undermining of every single aspect of their moral code, and thus is immoral in a way that nothing else possibly could be. And to the extent that it is immoral at an unprecedented level it must, of necessity, be offensive at an unprecedented level. (Cox 2014, p. 764)

A general objection that may be raised here is that no consensus exists with respect to the issue of whether God is the source of morality and the question, put forward by Plato, of whether something is approved of by the gods because it is pious, or rather pious because they approve of it (Plato 1967, 10a), inquired into thereafter in a monotheistic guise, has been answered in various ways, in no instance with a compelling argument. A second, for the present discussion more important, objection is that this standard unwarrantedly restricts the freedom of those who do not agree with it to express themselves (again, the issue is moot if all citizens acknowledge the standard). I say 'unwarrantedly': those who do not accept the ignore principle, or a similar principle, may reflect on the matter whether it is desirable to impose a moral standard on individuals.

Similarly, it is maintained that

it is as if the 'soul of the nation' is wounded by holocaust denial and it is for this reason that at a national, and not merely an individual, level its mere existence is regarded as so profoundly unacceptable that the state should reassert its public moral vision and prohibit such speech-whatever the cost to the holocaust denier's rights and interests. (Cox 2016, p. 212)

It is unclear what 'the state's public moral vision' could be. This presupposes that the state has a (single) moral vision, while it seems no more possible for a state, being, just as a community, an abstract entity or construct, to adopt a vision than a

\footnotetext{
23 Dworkin (1994, pp. 72 and 79). Elsewhere, Dworkin insists that it is not the view of the majority that is at issue: "when I speak of the community being faithful to its own principles I do not mean its conventional or popular morality, the beliefs and convictions of most citizens. I mean that the community has its own principles it can itself honor or dishonor, that it can act in good or bad faith, with integrity or hypocritically, just as people can.' Dworkin (1986, p. 168).
} 
standpoint; in a (liberal) democratic state, this vision would be the vision of the people. This is hardly helpful, though, since it is not, as has already been pointed out, realistic that all citizens share a single vision and, irrespective of that given, if one presumes (arguendo) that it is indeed the case that it is the moral vision of all citizens that Holocaust denial is wrong and should be prohibited, legislation to prohibit it would serve no purpose as no-one would (ex hypothesi) be inclined to use such speech in the first place.

If the foregoing analysis is accepted, no special protection can be claimed for 'sacred' items and alleged insults should be treated in the same way as insults in cases where something non-'sacred' is concerned. Pringle points to the following consequence of such a perspective: 'It is often considered desirable in liberal democracies to address religious insult or outrage not as sui generis but in terms of such neighbouring categories as offensiveness and obscenity', which results in blasphemy being 'drained of its very meaning in law' (Pringle 2011, p. 321). This is correct, but it does not follow from this consideration that religious insult or outrage should receive special treatment, and thus not be qualified as (mere) offensiveness or obscenity. Those who claim that such special treatment is in order bear the burden of proving why this is the case. Until they do so, blasphemy is indeed (and, I would add, properly so), drained of its meaning in law. Individuals may of course still personally consider certain expressions to attest to blasphemy, but bear, in that case, another burden, namely that of reasonably ignoring such expressions.

\section{Conclusion}

Expressions may be deemed blasphemous by individuals or groups of people and as such be offensive to them. In a pluralistic society it may be difficult to find shared values that transcend traditional religions. Certain ideas, such as the idea that murder should be forbidden, may be propagated from different perspectives but have a basis in the given that a failure to acknowledge them results in an undesirable outcome, regardless of one's individual convictions. By contrast, using a specific traditional religion as the basis for the claim of the divine right of a king would be difficult (apart from the constitutional issues this would raise in a liberal democratic state), just as it would be difficult to make it clear why it would follow from this claim that lèse-majesté should be an offence. This would not only presuppose that God (in a specific conception) exists, but also that a special association applies between God and the power that the king wields.

However, while the given that in a society in which such a specific conception, stemming from a traditional religion as a specific creed, is not generally accepted may result in the repeal of blasphemy laws that relate to that conception, other blasphemy laws may readily present themselves as their-veiled-successors. The threshold for expressions to qualify as blasphemous has tacitly been lowered, viz., without explicitly determining certain elements to be sacred and as such worthy of protection. Whether something is actually stated to be sacred is not as important, though, as is the latter element; the crucial issue is, in other words, not the definition 
of 'sacred', but rather the (special) protection certain elements receive. Rather than making every statement that may be considered blasphemous punishable, blasphemy should not be punishable at all.

Balancing the interests that are at stake, I have argued that there should be no special protection for what is 'sacred'. There should be no special religious insult laws and insult laws should not distinguish, in other words, between religious and non-religious insults. The title of Section is "Consistency one way or the other", and this is the first way to be consistent, acknowledging the religious worldview that citizens may have, on the basis of which they consider certain things sacred, without, at the same time, translating this acknowledgement into legislation so as to grant them a special protection. The alternative way to be consistent consists in granting every religious position and thus-since there is no universally agreed-upon definition of 'religion', everyone, accordingly, having the right to claim that a religious worldview is at stake-granting every citizen a special protection (thereby negating, incidentally, at the same time, any meaning of 'special'). Citizens are treated equally in both cases, but in the second case, the freedom to express oneself in a way that may be considered defamatory is compromised.

This does not entail that anything defamatory (which refers to [groups of] persons) should be allowed to be expressed, and certain defamatory statements should still be punishable, not on account of their being blasphemous, but rather on account of the fact that they are (sufficiently) harmful to those who are defamed. I have proposed a criterion to determine whether an expression is (sufficiently) harmful without appealing to religious elements: the ignore principle. This imposes a duty on those citizens who might be offended to ignore what they witness, or even to try to steer clear from expressions they know beforehand to be potentially offensive. Since they are not expected to ignore anything (potentially) offensive but only those expressions which they cannot reasonably ignore, however, their interests are taken seriously, just as the interests of those citizens who want to exercise the freedom of expression.

Open Access This article is licensed under a Creative Commons Attribution 4.0 International License, which permits use, sharing, adaptation, distribution and reproduction in any medium or format, as long as you give appropriate credit to the original author(s) and the source, provide a link to the Creative Commons licence, and indicate if changes were made. The images or other third party material in this article are included in the article's Creative Commons licence, unless indicated otherwise in a credit line to the material. If material is not included in the article's Creative Commons licence and your intended use is not permitted by statutory regulation or exceeds the permitted use, you will need to obtain permission directly from the copyright holder. To view a copy of this licence, visit http://creativecommons.org/licen ses/by/4.0/.

\section{References}

Aquinas, Thomas. 1895 [1274]. Summa Theologiae 2a2ae. Opera Omnia, vol. 8. Rome: S. C. de Propaganda Fide.

Aswad, Evelyn, Rashad Hussain, and M. Arsalan Suleman. 2014. Why the United States cannot agree to disagree. Boston University International Law Journal 32 (1): 119-146. 
Bielefeldt, Heiner. 2013. Report of the Special Rapporteur on freedom of religion or belief. 26 December. U.N. Doc. A/HRC/25/58.

Blum, Jason. 2018. Public discourse and the myth of religious speech. Journal of Contemporary Religion 33 (1): $1-16$.

Brent Plate, S. 2006. Blasphemy. Art that offends. London: Black Dog Publishing.

Burns Coleman, Elizabeth, and Kevin White. 2006. Stretching the sacred. In Negotiating the sacred. Blasphemy and sacrilege in a multicultural society, ed. Elizabeth Burns Coleman and Kevin White, 65-77. Canberra: The Australian National University Press.

Cox, Neville. 2014. Blasphemy, Holocaust denial, and the control of profoundly unacceptable speech. American Journal of Comparative Law 62 (3): 739-774.

Cox, Neville. 2016. The freedom to publish 'irreligious' cartoons. Human Rights Law Review 16 (2): $195-221$.

Doomen, Jasper. 2016. Beyond dignity. Archiv für Begriffsgeschichte 57: 57-72.

Doomen, Jasper. 2014. Freedom and equality in a liberal democratic state. Brussels: Bruylant.

Durkheim, Émile. 1960 [1912]. Les formes élémentaires de la vie religieuse. Paris: Quadrige/Presses Universitaires de France.

Dutch Supreme Court. June 5, 1987. case no. 13274 (civil case)/November 18, 1988; case no. 83732 (criminal case).

Dworkin, Ronald. 1986. Law's empire. Cambridge, MA/London: The Belknap Press of Harvard University Press.

Dworkin, Ronald. 1994. Life's dominion. New York: Vintage Books.

Holzapfel, Caleb. 2014. Can I say that? How an international blasphemy law pits the freedom of religion against the freedom of speech. Emory International Law Review 28 (1): 597-648.

Jones, Richard. 1989. 'In god we trust' and the establishment clause. Journal of Church and State 31 (3): 381-417.

Kahn, Robert. 2011. Holocaust denial and hate speech. In Genocide denials and the law, ed. Ludovic Hennebel and Thomas Hochmann, 77-108. New York: Oxford University Press.

MacIntyre, Alasdair. 2007 [1981]. After virtue. Notre Dame, IN: University of Notre Dame Press.

Moon, Richard. 2018. Putting faith in hate. When religion is the source or target of hate speech. Cambridge: Cambridge University Press.

Patrick, Jeremy. 2011. The curious persistence of blasphemy. Florida Journal of International Law 23 (2): 187-220.

Plato. 1967 [ \pm 386 BCE]. Euthyphro. Platonis Opera, vol. 1, ed. John Burnet. London/New York: Oxford University Press.

Pringle, Helen. 2011. Regulating offence to the godly: Blasphemy and the future of religious vilification. University of New South Wales Law Journal 34 (1): 316-332.

Tatz, Colin. 2006. Sacralising the profane, profaning the sacred. In Negotiating the sacred. Blasphemy and sacrilege in a multicultural society, ed. Elizabeth Burns Coleman and Kevin White, 79-88. Canberra: The Australian National University.

Yelle, Robert. 2014. Secular blasphemies. Symbolic offense in modern democracy. In Profane: Sacrilegious expression in a multicultural age, ed. Christopher Grenda, Chris Beneke, and David Nash, 141-166. Oakland, CA: University of California Press.

Publisher's Note Springer Nature remains neutral with regard to jurisdictional claims in published maps and institutional affiliations. 